\title{
Effects of sex and genotype on performance and yield characteristics of free range broiler chickens
}

\author{
[Avaliação dos efeitos de sexo e genótipo sobre características de desempenho e \\ rendimento em frangos tipo caipira] \\ C.C. Del Castilho ${ }^{1}$, T.T, Santos $^{2}$, C.A.F. Rodrigues ${ }^{1}$, R.A. Torres Filho ${ }^{1}$ \\ ${ }^{1}$ Faculdade de Veterinária da Universidade Federal Fluminense- Niterói, RJ \\ ${ }^{2}$ AB Vista/AB Agri Ltd, Marlborough, UK
}

\begin{abstract}
The purpose of this work was to evaluate the effect of genotype and sex on the performance characteristics (weight gain, feed conversion and livability) and yields (carcass, breast and legs) of six free-range genotypes: Pesadão Vermelho (GEN1), Carijó (GEN2), Pescoço Pelado 1 (GEN3), Pescoço Pelado 2 (GEN4), Pescoço Pelado 3 (GEN5) and Pescoço Pelado 4 (GEN6). A total of 1584 sexed one day old chicks ( 792 males and 792 females) were housed in 48 pens, 33 birds per pen. The experimental design was a completely randomized factorial $2 \times 6$ (six genotypes and two sexes) design, with four replicates each. Diets were based on corn and soybean meal (no animal protein) provided in a feeding program in four phases: pre-starter (1 to 21 days), starter (22 to 42 days), growth (43 to 77 days) and finisher (78 to 91 days). Feed intake, feed conversion and livability were measured at 21, 42, 77 and 91 days of age. There was no genotype $\mathrm{x}$ sex interaction. The effect of sex was observed in all ages regarding weight gain, feed conversion (except at 21 days) and yields. For all these characteristics, males performed better than females, except in breast yield, which was higher in females. For the livability and feed conversion at 21 days no effect of sex was found. The effect of genotype was observed only in carcass and breast yields. The fast (GEN1) and intermediate (GEN2, GEN5 and GEN6) growing genotypes showed higher weight gain than the slow growing genotypes (GEN4 and GEN3). Carcass and breast yields of naked neck genotypes (GEN3, GEN4, GEN5 and GEN6) did not differ among themselves, and were higher than the Carijó genotype (GEN2) and are therefore recommended for production systems that sell industrialized birds.
\end{abstract}

Keywords: alternative aviculture, genotype, performance, yields

\section{RESUMO}

A realização deste trabalho buscou avaliar o efeito de genótipo, sexo e sua interação sobre as características de desempenho (ganho de peso, conversão alimentar e viabilidade) e de rendimento (carcaça, peito e pernas) de seis genótipos de frango de corte tipo caipira: Pesadão Vermelho (GEN1), Carijó (GEN2), Pescoço Pelado 1 (GEN3), Pescoço Pelado 2 (GEN4), Pescoço Pelado 3 (GEN5) e Pescoço Pelado 4 (GEN6). Foram utilizados 1584 pintinhos sexados (792 machos e 792 fêmeas), alojados em 48 boxes, sendo 33 aves por boxe. O delineamento experimental foi o inteiramente ao acaso, em esquema fatorial $6 \times 2$ (seis genótipos e dois sexos), com quatro repetições cada, sendo cada boxe considerado uma unidade experimental. As rações à base de milho e farelo de soja (sem proteínas de origem animal) foram fornecidas em um programa de alimentação de quatro fases:pré-inicial (um a 21 dias), inicial (22 a 42 dias), crescimento (43 a 77 dias) e abate (78 dias até o abate). As variáveis foram medidas aos 21, 42, 77 e 91 dias de idade. Não foi observado efeito da interação sexo x genótipo. Foi observado efeito de sexo, em todas as idades avaliadas para ganho de peso, conversão alimentar (exceto aos 21 dias) e rendimentos. Para todas essas características, os machos apresentaram melhor desempenho que as fêmeas, exceto no rendimento de peito. Para a viabilidade e a conversão alimentar

Recebido em 15 de março de 2012

Aceito em 13 de junho de 2013

E-mail: claudiacris82@yahoo.com.br 
aos 21 dias não foi encontrado efeito de sexo. Efeito de genótipo foi observado apenas nas características ganho de peso e rendimento de carcaça e peito. Os genótipos de crescimento rápido (GEN1) e intermediário (GEN2, GEN5 e GEN6) apresentaram melhor desempenho em relação a ganho de peso do que os genótipos de crescimento lento (GEN3 e GEN4). Para o rendimento de carcaça e peito, os genótipos de Pescoço Pelado (GEN3, GEN4, GEN5 e GEN6) não diferiram entre si e apresentaram rendimentos maiores que o genótipo Carijó (GEN2), sendo recomendáveis para sistemas de produção que vendem aves industrializadas.

Palavras-chave: avicultura alternativa, genótipos, desempenho, rendimentos

\section{INTRODUCTION}

The alternative production of broiler chickens has become a relevant activity for small producers from different regions of Brazil, both for their subsistence on farms as well as for commercial production (Hellmeister Filho, 2002).

Also called "caipira" (Southeast), "colonial" (Southern Region) and "capoeira" (Northeast) in Brazil, the broiler for alternative production has been genetically improved to achieve the best performance and highest yields (Figueiredo et al., 2001; Takahashi, 2003). Several authors (Hellmeister Filho et al. 2003; Fanatico et al., 2005; Santos et al., 2005a; Santos et al., 2005b; Takahashi et al., 2006; Savino et al., 2007) observed significant differences between genotypes indicated for free-range systems, regarding the performance and/or the carcass yields.

The diversity among the production systems of free range broilers goes from extremely extensive systems, where there is little or no addition of technology, to modern systems where the cost of production is primordial; in the last case, genotypes showing higher efficiency are required.

Among the many authors who evaluated freerange genotypes, Fanatico et al. (2005) and Takahashi et al. (2006) found no significant interaction between genotype and production system. By raising the animals in an intensive production system the birds can express their maximum growth potential, and thus the genotypes can be better differentiated.

The aim of this trial was to evaluate different genotypes recommended for free-range poultry production, under intensive production conditions, focused on animal performance and carcass yield.

\section{MATERIALS AND METHODS}

The experiment was conducted at Centro de Tecnologia Avícola da Globoaves (CTA) in the period from $02 / 16 / 2007$ to $05 / 18 / 2007$. The Experimental Station is divided into $2.0 \times 1.75 \mathrm{~m}$ pens, with a $3.5 \mathrm{~m}^{2}$ area each. Given that the goal was to assess the maximum potential growth of each genotype, the birds had no access to the paddock. New pine shavings were used as litter.

Initially, eggs were incubated simultaneously in the same commercial hatchery (Globoaves Agro Avicola Ltda) in Cascavel - Paraná. After hatching, the chicks were sexed and vaccinated against Marek Disease, Bouba, Gumboro and Newcastle. A total of 1584 sexed day old chicks (792 males and 792 females) from eggs from six commercial genotypes of free-range broilers were divided in $482.0 \times 1.75 \mathrm{~m}$ pens with 33 birds/pen.

The experimental design was completely randomized in a 6x2 factorial design (six genotypes and two sexes), with four replicates.

The genotypes used in this study are described below:

- Genotype 1: red plumage with black tail feathers (Commercial Name: Pesadão Vermelho), origin: Colonial Line;

- Genotype 2: barred plumage type (Commercial Name: Carijó), origin: Colonial Line;

- Genotype 3: naked neck gene and red plumage with black tail feathers (Commercial Name: Pescoço Pelado), origin: Sasso - X-S31 (origin 3);

- Genotype 4: naked neck gene and red plumage with black tail feathers (Commercial Name: Pescoço Pelado), origin ISA - JA57 (origin 3); 
- Genotype 5: naked neck gene and red plumage with black tail feathers (Commercial Name: Pescoço Pelado - code M1T1), origin: Colonial Line;

- Genotype 6: naked neck gene and red plumage with black tail feathers (source 2) (Commercial Name: Pescoço Pelado - code M2T1), origin: Colonial Line.

Genotypes 1, 2, 5 and 6 are materials developed by the breeding program from Globoaves Agro Avícola Ltda, whose lineage is called Colonial, and with the exception of genotype 1, the program aims to develop intermediate growth birds. Genotypes 3 and 4 are of French origin, being recommended for the markets that require slow growth.
The chicks were housed with one day of age, received the vaccination in accordance to technical advice, water and feed ad libitum. The system adopted was intensive, since the goal is to identify among the group of genotypes recommended for alternative aviculture those with greater growth potential. Thus the experiment was conducted to provide conditions for each genotype to express the maximum development potential.

The feeds were formulated based on corn and soybean meal diet without animal protein and nutritional levels used in free-range broiler chickens (Tab. 1). The feeding program has four phases: Pre Starter (1 to 21 days), Starter (22 to 42 days), Growth (43 to 77 days) and Finisher (78 - 91 days).

Table 1. Composition and nutrient levels of experimental diets

\begin{tabular}{|c|c|c|c|c|}
\hline Nutrient & $\begin{array}{l}\text { Pre Starter } \\
(0-21 d)\end{array}$ & $\begin{array}{c}\text { Starter } \\
(22-42 d)\end{array}$ & $\begin{array}{l}\text { Growth } \\
\text { (43-77d) }\end{array}$ & $\begin{array}{l}\text { Finisher } \\
\text { (78-91d) }\end{array}$ \\
\hline Corn, \% & 62.3 & 65.0 & 70.7 & 73.7 \\
\hline Soybean Meal, \% & 33.0 & 27.4 & 20.9 & 18.8 \\
\hline Corn Gluten Meal, \% & - & 3.0 & 4.0 & 4.0 \\
\hline Dic. Phosphate, \% & 1.7 & 1.5 & 1.2 & 0.8 \\
\hline Limestone, \% & 1.5 & 1.4 & 1.2 & 1.0 \\
\hline Salt, $\%$ & 0.5 & 0.4 & 0.4 & 0.4 \\
\hline Veg. Oil, \% & 0.2 & 0.5 & 0.8 & 0.7 \\
\hline Lysine $\mathrm{HCl}, \%$ & 0.1 & 0.2 & 0.3 & 0.2 \\
\hline MHA, $\%$ & 0.3 & 0.2 & 0.1 & - \\
\hline Premix $* \%$ & 0.4 & 0.4 & 0.4 & 0.4 \\
\hline $\mathrm{ME}(\mathrm{kcal} / \mathrm{kg})$ & 2850 & 2950 & 3050 & 3090 \\
\hline $\mathrm{CP}(\%)$ & 20.00 & 19.50 & 17.50 & 16.80 \\
\hline $\mathrm{Ca}(\%)$ & 1.05 & 0.95 & 0.80 & 0.65 \\
\hline Pdisp (\%) & 0.45 & 0.40 & 0.33 & 0.26 \\
\hline Lysine dig (\%) & 1.00 & 0.94 & 0.82 & 0.74 \\
\hline AAST $\operatorname{dig}(\%)$ & 0.77 & 0.71 & 0.61 & 0.55 \\
\hline Tryptophan dig (\%) & 0.21 & 0.19 & 0.16 & 0.16 \\
\hline Threonine dig $(\%)$ & 0.65 & 0.62 & 0.55 & 0.52 \\
\hline Sodium $(\%)$ & 0.24 & 0.19 & 0.19 & 0.19 \\
\hline Potassium (\%) & 0.88 & 0.77 & 0.66 & 0.62 \\
\hline Chloride (\%) & 0.37 & 0.31 & 0.31 & 0.30 \\
\hline
\end{tabular}

*Provided per kg of feed: Vitamin A 8000U; Vitamin D3 3000U; Vitamin E 15mg; Vitamin K3 1.8mg; Vitamin B1 2.5mg; Vitamin B2 8.0mg; Vitamin B6 3.5mg; Vitamin B12 12mcg; Niacin 40mg; Pantotenic acid 15mg; Folic acid 1mg; Biotin 60mcg; Iron 60mg; Coper 8mg; Zinc 100mg; Manganese 120mg; Iodine 1mg; Selenium 300mcg.

In the hatchery the chicks were weighed and this weight was considered weight to one day. Mortality was monitored daily, and the average feed intake and average body weight were measured at 21, 42, 77 and 91 days old.
At 91 days 2 birds per pen were selected based on the pen average weight and sacrificed by cervical dislocation for carcass, breast and leg yield determination.

Statistical analysis of data collected in this completely randomized design was performed 
using the $\mathrm{SAS}^{\circledR}$ statistical program. The descriptive analyses of data were conducted to verify the assumptions of analysis of variance $(F$ test), which demonstrated the need to transform the feed conversion, livability and yield variables. This transformation was done by the base $10 \log$ scales.

Analysis of variance was performed using the following statistical model:

$$
Y_{i j k}=\mu+G_{i}+S_{j}+(G S)_{i j}+e_{i j k},
$$

where $\mathrm{i}=1, . ., 6, \mathrm{j}=1.2, \mathrm{k}=1, \ldots, 4 ; \mathrm{Y}$ is the value observed in the $i$-th genotype and $j$-th sex of the k-th repetition, $\mu$ is the general constant all observations; $\mathrm{Gi}$ is the effect of $\mathrm{i}$-th genotype; $\mathrm{Sj}$ is the effect of $\mathrm{j}$-th sex; (GS) ij is the interaction between genotype $\mathrm{i}$ and $\operatorname{sex} \mathrm{j}$; and eijk is the error (random).

The comparison of averages was performed by Tukey test at $5 \%$ probability.

\section{RESULTS AND DISCUSSION}

There was no significant effect $(\mathrm{P}<0.05)$ of interaction between sex and genotype in all variables, therefore all results will show the main effects. Table 2 shows the averages by sex.

Table 2. Averages of body weight, weight gain, feed conversion, livability and yield by sex

\begin{tabular}{lccc}
\multicolumn{1}{c}{ Feature } & Male & Female & General \\
\hline Weight gain $(\mathrm{kg})$ from 0 to 21 days & $0.385^{\mathrm{A}}$ & $0.370^{\mathrm{B}}$ & 0.377 \\
Weight gain (kg) from 0 to 42 days & $1.123^{\mathrm{A}}$ & $1.016^{\mathrm{B}}$ & 1.069 \\
Weight gain (kg) from 0 to 77 days & $2.756^{\mathrm{A}}$ & $2.310^{\mathrm{B}}$ & 2.533 \\
Weight gain (kg) from 0 to 91 days & $3.195^{\mathrm{A}}$ & $2.677^{\mathrm{B}}$ & 2.936 \\
Feed conversion (g:g) at 21 days & $1.687^{\mathrm{A}}$ & $1.708^{\mathrm{A}}$ & 1.697 \\
Feed conversion (g:g) at 42 days & $2.287^{\mathrm{A}}$ & $2.367^{\mathrm{B}}$ & 2.327 \\
Feed conversion (g:g) at 77 days & $2.634^{\mathrm{A}}$ & $2.792^{\mathrm{B}}$ & 2.713 \\
Feed conversion (g:g) at 91 days & $2.930^{\mathrm{A}}$ & $3.114^{\mathrm{B}}$ & 3.022 \\
Livability (\%) at 21 days & $98.48^{\mathrm{A}}$ & $99.62^{\mathrm{A}}$ & 99.05 \\
Livability (\%) at 42 days & $98.48^{\mathrm{A}}$ & $99.49^{\mathrm{A}}$ & 98.99 \\
Livability (\%) at 77 days & $98.11^{\mathrm{A}}$ & $99.37^{\mathrm{A}}$ & 98.74 \\
Livability (\%) at 91 days & $97.22^{\mathrm{A}}$ & $97.95^{\mathrm{A}}$ & 97.59 \\
Carcass yield (\%) & $75.93^{\mathrm{A}}$ & $74.30^{\mathrm{B}}$ & 75.12 \\
Breast yield $(\%)$ & $23.13^{\mathrm{B}}$ & $25.27^{\mathrm{A}}$ & 24.20 \\
Leg yield $(\%)$ & $27.03^{\mathrm{A}}$ & $25.62^{\mathrm{B}}$ & 26.32 \\
\hline
\end{tabular}

*Means followed by the same letter in a column were not significantly different at $5 \%$ probability by the Tukey test.

Besides being originated from different lines, initial body weight was not affected by the genetics or sex. Body weight gain for males was significantly higher than females in all further determinations. Lana et al. (2000) and Viana et al. (2000) found similar results, with higher average body weight for males of broiler strains at 42 days old.

Fanatico et al. (2005) report that the effect of the sex on the weight of the birds is usually observed in broilers and that the difference tends to increase with advancing age, whereas in the case of slow-growing birds, which are slaughtered at higher ages, this feature can generate a greater uniformity of lots. At 91 days, for example, the weight difference between males and females in this experiment was 518 grams, agreeing with the affirmation of Fanatico et al. (2005), that differ from the results of Santos et al. (2005a) who observed no significant differences between males and females of naked neck chickens ISA Label line at 49, 77 and 105 days of age.

Regarding feed conversion, the sex effect was not observed at the age of 21 days. In all other ages males had better feed conversion than females, indicating their greater feed efficiency. Similar results were reported by Santos et al. (2005a) who, in the same study mentioned above, found better feed conversion for males from the ISA Label at 49, 77 and 105 days of age.

There was no effect of sex on bird's livability, a result also observed by Hellmeister Filho (2002), who worked with different genotypes recommended for free-range systems.

Regarding yields, the sex effect was observed in all evaluated characteristics, with males 
containing statistically higher carcass and leg yields $(1.63 \%$ and $1.51 \%$, respectively) and lower breast yield $(2.14 \%)$. The higher average carcass and leg and lower breast yield were also observed in males in the work of Mendes et al. (1993), Hellmeister Filho (2002), Fanatico et al. (2005) and Santos et al. (2005a).

Takahashi et al. (2006) compared yields of freerange strains carcasses at 56, 63, 70, 77 and 84 days of age, with no significant differences between sexes at 70 and 84 days, but higher yields in males. For leg and breast yields, significant effects were observed at all ages, being the males and females ratio equal to the present study.

The differences found between males and females can be explained due to the sexual dimorphism between males and females. Gonzales and Sartori (2002) note that the muscle development of broilers occurs through the interaction of several factors, among which sex and hormonal factors have significant influence. Since males have more androgen hormones responsible for muscle anabolism, they have higher growth rates than females, which helps in understanding the higher weight of males found in this work. It is noteworthy that these are not the only hormones involved in muscle development, but also GH hormones, thyroid hormones and glucocorticoids.

Mendes et al. (2004) discuss that females have smaller muscle fibers than males of the same age, so the increase in fiber diameter due to constant muscular exercise is different according to the sex, being higher in males as well as the response rate growth compared to the protein / energy ration. This contributes both to the difference in the growth rate and to the difference in efficiency of feed between sexes, such differences observed in this study.

Tables 3, 4, 5 and 6 show the comparison of the average body weight, weight gain, feed conversion and livability of the birds at 21,42 , 77 and 91 days respectively for the effect of genotype.

Table 3. Weight gain, feed conversion and livability of the genotypes from 0 to 21 days of age

\begin{tabular}{cccc}
\hline Genotype & Weight gain $(\mathrm{kg})$ & Feed conversion $(\mathrm{g}: \mathrm{g})$ & Livability $(\%)$ \\
\hline GEN1 & $0.387^{\mathrm{A}}$ & 1.696 & 99.24 \\
GEN2 & $0.367^{\mathrm{B}}$ & 1.706 & 98.86 \\
GEN3 & $0.373^{\mathrm{AB}}$ & 1.672 & 98.86 \\
GEN4 & $0.369^{\mathrm{B}}$ & 1.695 & 98.48 \\
GEN5 & $0.381^{\mathrm{AB}}$ & 1.695 & 99.62 \\
GEN6 & $0.387^{\mathrm{A}}$ & 1.718 & 99.24 \\
\hline
\end{tabular}

* Means followed by the same letter in a column were not significantly different at $5 \%$ probability by Tukey test.

Table 4. Weight gain, feed conversion and livability of the genotypes from 0 to 42 days of age

\begin{tabular}{cccc}
\hline Genotype & Weight gain $(\mathrm{kg})$ & Feed conversion $(\mathrm{g}: \mathrm{g})$ & Livability $(\%)$ \\
\hline GEN1 & $1.111^{\mathrm{A}}$ & 2.339 & 99.24 \\
GEN2 & $1.080^{\mathrm{AB}}$ & 2.296 & 98.86 \\
GEN3 & $1.026^{\mathrm{BC}}$ & 2.340 & 98.86 \\
GEN4 & $1.006^{\mathrm{C}}$ & 2.354 & 98.10 \\
GEN5 & $1.095^{\mathrm{A}}$ & 2.307 & 98.62 \\
GEN6 & $1.098^{\mathrm{A}}$ & 2.322 & 99.24 \\
\hline
\end{tabular}

* Means followed by the same letter in a column were not significantly different at $5 \%$ probability by Tukey test.

Table 5. Weight gain, feed conversion and livability of the genotypes from 0 to 77 days of age

\begin{tabular}{cccc}
\hline Genotype & Weight gain $(\mathrm{kg})$ & Feed conversion $(\mathrm{g}: \mathrm{g})$ & Livability $(\%)$ \\
\hline GEN1 & $2.690^{\mathrm{A}}$ & 2.707 & 99.24 \\
GEN2 & $2.553^{\mathrm{B}}$ & 2.691 & 98.48 \\
GEN3 & $2.390^{\mathrm{C}}$ & 2.696 & 98.86 \\
GEN4 & $2.342^{\mathrm{C}}$ & 2.739 & 98.10 \\
GEN5 & $2.582^{\mathrm{B}}$ & 2.705 & 98.86 \\
GEN6 & $2.642^{\mathrm{AB}}$ & 2.741 & 98.86 \\
\hline
\end{tabular}

* Means followed by the same letter in a column were not significantly different at $5 \%$ probability by Tukey test. 
Table 6. Weight gain, feed conversion and livability of the genotypes from 0 to 91 days of age

\begin{tabular}{cccc}
\hline Genotype & Weight gain $(\mathrm{kg})$ & Feed conversion $(\mathrm{g}: \mathrm{g})$ & Livability $(\%)$ \\
\hline GEN1 & $3.130^{\mathrm{A}}$ & 3.025 & 97.72 \\
GEN2 & $2.979^{\mathrm{B}}$ & 3.012 & 98.10 \\
GEN3 & $2.789^{\mathrm{C}}$ & 2.985 & 98.10 \\
GEN4 & $2.716^{\mathrm{C}}$ & 3.036 & 96.59 \\
GEN5 & $2.952^{\mathrm{B}}$ & 3.018 & 97.65 \\
GEN6 & $3.050^{\mathrm{AB}}$ & 3.054 & 97.34
\end{tabular}

* Means followed by the same letter in a column were not significantly different at 5\% probability by Tukey test.

After 21 days, GEN1 and GEN6 had the highest weight gains, followed by GEN3, GEN5, GEN2 and GEN4.

From 42 days, note that GEN1 and GEN6 follow with the highest mean weight gain up to 91 days, while the lowest averages are found in GEN3 and GEN4.

Hellmeister Filho et al. (2003), evaluating freerange chicken strains with fast and slow growth, found the same effect on the trait of weight gain (from 60 days of age), and those of fast growth had higher averages in relation to slow growth.

The results presented here do not agree with the findings of Santos et al. (2005a), who reported no significant difference in weight gain of Paraíso Pedrês and ISA Label birds at 49, 77 and 105 days and Fanatico et al. (2005) who also found no significant difference in free-range birds of fast and slow growth at 67 and 81 days old, respectively.

In feed conversion ratio, it can be observed that there was no significant effect of genotype on this feature in any of the ages. Barbosa Filho et al. (2005) found similar results, obtaining no significant differences between the average feed conversion between different genotypes of freerange chickens at 75 days of age.
Different results were reported by Hellmeister Filho et al. (2003) who observed genotype effect, getting the best averages of feed conversion for free-range broiler chickens with fast and slow growth comparison. Savino et al. (2007) evaluated eight genotypes of free-range chickens and found no effect of genotype on feed conversion only at 28 days and not at 56 and 84 days of age.

The livability values did not suffer significant effect of genotype. We also observed that livability shows very high values, according to the results of Hellmeister Filho et al. (2003), who found low levels of mortality, suggesting high livability of different genotypes, which is an important factor, since this system requires greater resistance of birds.

The similar livability between genotypes indicates that the selection practiced in the genotypes of intermediate growth did not change the resistance of these birds, which continue with the good livability characteristic of the slow growth birds.

Yield values for carcass, breast and legs are described in Table 7.

Table 7. Bird yields per genotype

\begin{tabular}{cccc}
\hline Genotype & Carcass yield $(\%)$ & Breast yield $(\%)$ & Leg yield $(\%)$ \\
\hline GEN1 & $74.42^{\mathrm{AB}}$ & $23.89^{\mathrm{AB}}$ & $26.20^{\mathrm{A}}$ \\
GEN2 & $72.87^{\mathrm{B}}$ & $22.91^{\mathrm{B}}$ & $25.74^{\mathrm{A}}$ \\
GEN3 & $75.35^{\mathrm{A}}$ & $23.84^{\mathrm{A}}$ & $26.65^{\mathrm{A}}$ \\
GEN4 & $75.83^{\mathrm{A}}$ & $24.95^{\mathrm{A}}$ & $26.48^{\mathrm{A}}$ \\
GEN5 & $76.25^{\mathrm{A}}$ & $24.83^{\mathrm{A}}$ & $26.60^{\mathrm{A}}$ \\
GEN6 & $75.97^{\mathrm{A}}$ & $24.81^{\mathrm{A}}$ & $26.27^{\mathrm{A}}$ \\
\hline
\end{tabular}

* Means followed by the same letter in a column were not significantly different at $5 \%$ probability by Tukey test. 
For carcass and breast yields, the four genotypes of phenotype naked neck (GEN3, GEN4, GEN5 and GEN6) did not differ, being higher than the yields obtained by the phenotype Carijó (GEN2), as shown in Tab. 7. Thus, genotypes with naked neck are recommended for production systems that sell industrialized birds.

Fanatico et al. (2005) reported a genotype effect on the yield of the birds. In their study, higher carcass and breast yields were observed for a fast growing genotype in comparison to a slow growing genotype, both raised with access to pasture area. The leg yield, however, was higher for the slow growth genotype.

Takahashi et al. (2006) found no effect of genotype in free-range birds only in carcass yield at 63 and 84 days of age. The values of breast and leg yields in all the evaluated ages $(56,63$, 70,77 and 84 days) showed no significant difference between genotypes.

\section{CONCLUSIONS}

The genotypes selected for intermediate growth (GEN1, GEN5 and GEN6) had better weight gain than the slow growth genotypes (GEN3 and GEN4). Males had superior carcass and leg yields while females had better breast yield. The genotypes of naked neck phenotype (GEN3, GEN4, GEN5 and GEN6) are recommended for industrial production because they had better carcass, breast and leg yields.

\section{ACKNOWLEDGEMENTS}

To FAPERJ (Fundação de Amparo à Pesquisa do Estado do Rio de Janeiro) for the financial support which made this project possible; to CAPES (Coordenação de Aperfeiçoamento de Pessoal de Nível Superior) for the concession of the scholarship assistance and to the Globoaves company for providing the data bank.

\section{REFERENCES}

BARBOSA FILHO, J.A.D.; SILVA, M.A.N.; SILVA, I.J.O. et al. Behavior and Performance of Broiler Strains Reared under Semi-intensive System with Shaded Areas. Rev. Bras. Cienc. Avic., v.7, p.209-213, 2005.
FANATICO, A.C.; PILLAI, P.B.; CAVITT, L.C. et al. Evaluation of Slower-Growing Broiler Genotypes Grown with and Without Outdoor Access: Growth Performance and Carcass Yield. Poult. Sci., v.84, p.1321-1327, 2005.

FIGUEIREDO, E.A.P.; PAIVA, D.P.; ROSA, P.S. et al. Diferentes denominações e classificação brasileira de produção alternativa de frangos. In: CONFERÊNCIA APINCO DE CIÊNCIA E TECNOLOGIA APÍCOLAS, 2., 2001, São Paulo. Anais... Campinas: Fundação Apinco de Ciência e Tecnologias Avícolas, 2001. p.209222.

GONZALES, E.; SARTORI, J.R. Crescimento e metabolismo muscular. In: MACARI, M.; FURLAN, R.L.; GONZALES, E. (Ed.). Fisiologia aviária aplicada a frangos de corte. Jaboticabal: FUNEP/UNESP, 2002. p.279-297.

HELLMEISTER FILHO, P. Efeitos de Fatores Genéticos e do Sistema de Criação sobre o Desempenho e o Rendimento de Carcaça de Frangos Tipo Caipira. 2002. 77f. Tese (Doutorado em Agronomia). Universidade de São Paulo, Piracicaba.

HELLMEISTER FILHO, P.; MENTEN, J.F.M.; SILVA, M.A.N. et al. Efeito de Genótipo e do Sistema de Criação sobre o Desempenho de Frangos Tipo Caipira. Rev. Bras. Zootec., v.32, p.1883-1889, 2003.

LANA, G.R.Q.; ROSTAGNO, H.S.; ALBINO L.F.T.; LANA, A.M.Q. Efeito da Temperatura Ambiente e da Restrição Alimentar sobre o Desempenho e a Composição da Carcaça de Frangos de Corte. Rev. Bras. Cienc. Avic., v.29, p.1117-1123, 2000.

MENDES, A.A.; GARCIA, E.A.; GONZALEZ, E. Efeito de linhagem e idade de abate sobre o rendimento de carcaça de frangos de corte. Rev. Bras. Zootec., v.22, p.466-472, 1993.

MENDES, A.A.; NÄÄS, I.A.; MACARI, M. Produção de Frangos de Corte. Campinas: FACTA, 2004. 356p.

SAVINO, V.J.M.; COELHO, A.A.D.; ROSÁRIO, M.F.; SILVA, M.A.N. Avaliação de materiais genéticos visando à produção de frango caipira em diferentes sistemas de alimentação. Rev. Bras. Zootec., v.36, p.578-583, 2007. 
SANTOS, A.L.; SAKOMURA, N.K.; FREITAS, E.R. et al. Comparison of Free Range Broiler Chicken Strains Raised in Confined or SemiConfined Systems. Rev. Bras. Cienc. Avic., v.7, p.85-92, 2005a.

SANTOS, A.L.; SAKOMURA, N.K.; FREITAS, E.R. et al. Estudo do Crescimento, Desempenho, Rendimento de Carcaça e Qualidade de Carne de Três Linhagens de Frango de Corte. Rev. Bras. Zootec., v.34, p.1589-1598, 2005b.

TAKAHASHI, S.E. Efeito do Sistema de Criação sobre o Desempenho e Qualidade da Carne de Frangos de Corte Tipo Colonial e Industrial. 2003. 64f. Dissertação (Mestrado em Nutrição e Produção Animal). Universidade Estadual Paulista, São Paulo.
TAKAHASHI, S.E.; MENDES, A.A.; SALDANHA, E.S.P.B. et al. Efeito do sistema de criação sobre o desempenho e rendimento de carcaça de frangos de corte tipo colonial. Arq. Bras. Med. Vet. Zootec., v.58, p.624-632, 2006.

VIANA, C.F.A.; SILVA, M.A.; PIRES, A.V. et al. Influência de Grupos Genéticos e de Níveis de Energia sobre Características de Carcaça de Frangos de Corte. Rev. Bras. Zootec., v.29, p.1067-1073, 2000. 